\title{
Teacher's Strategies In Teaching Speaking During Covid-19 Pandemic
}

\author{
Arya Fitri \\ UPGRI Palembang \\ aryafitri887@gmail.com \\ Hermansyah \\ UPGRI Palembang \\ hermansyah@univpgri-palembang.ac.id \\ Etty Pratiwi \\ UPGRI Palembang \\ ettypratiwi1998@gmail.com \\ Aswadijaya \\ aswadijaya@yahoo.com \\ Corresponding email: aryafitri887@gmail.com
}

\begin{abstract}
The Covid-19 Pandemic situation made the Government announce online learning activities. This policy and it was relationship with teacher strategy at interesting teaching to learn. So that, This research was focused on the strategy that the teacher and used in impelemanting learning during the Covid-19 pandemic. Namely distance learning (PJJ), so that it could runned effectively, optimally, and run well. This research aimed to describe the strategy of teachers in teaching Speking during the Covid-19 Pandemic. This research used a descriptive qualitative approach. The research subject was class VIIB English teacher, and grade VIIB students. Data collection techniques in this research were observation, interviews, and documentation. The results of the research show that the teacher used an expository strategy that emphasized the teaching and learning process directed to achieve learning objectives. Analysis of online teacher learning methods with virtual media as a supporting means used two learning methods, first, the assignment method through the google classroom application, the results of the answer sheets were collected directly to the school, and then the second learning method was question and answer through Zoom Meeting and WhatsApp Group. The conclusion obtained from this research was that the teacher strategy in teaching speaking at Junior High School Prabumulih during the Covid-19 Pandemic could be seen from: teaching objectives, teaching approach, and teaching methods.
\end{abstract}

Keywords: Teacher Strategy, Speaking. Covid-19 Pandemic.

\section{Introduction}

Education is a learning experience to make that contains aspects of competence, namely skills and creativity, skills are meant in exploration experiences to train abilities and increase knowledge. Education as a system- 
systemic conscious effort always start from a number of foundations and heeds a number of these principles (Sulo, 2005). Foundations and principles are very important because education is the main principle in developing human knowledge as an educational goal. Education aims to help develop cognitive potential, language potential and socio-emotional potential. The task of educating is carried out correctly and precisely according to educational goals.

The learning process is said to be successful if the factors that affect the learning process can play an active role in making students understand and understand the knowledge conveyed. And of course the factors that greatly influence the learning process are none other than teachers or educators. The teacher is a very dominant and most important factor in formal education in common, because teachers are often used as role models for students and even become self-identified figures (Daryanto, 2010). Therefore, teachers have the behavior and ability to develop their students completely. and carry out their duties properly in accordance with the profession they have, so teachers need to master knowledge as their competence. In languange learning, There are four skills: listening, speaking, reading, and writing, According to (Anjayani $P, 2016)$, Productive skills is the term for speaking skills where students actually have to produce language themselves.

In Indonesia, the changed paradigm in learning English is not followed by the change in students' proficiency in speaking English. Although it was found that the position of Indonesia in terms of the score of English proficiency has increased for the last three years based on Education First-English Proficiency Index (EF-EPI) (Jaya, 2019). In an effective learning process, teachers have very important strategies during the teaching and learning process. The teacher is the main learning component because the success of the teaching and learning process is determined by the teacher. In improving the quality of learning in the classroom, the competence of a professional teacher must be able to create a pleasant learning atmosphere and make students feel 
comfortable studying with their teacher, to be able to plan and carry out conducive learning, design and evaluate and develop students potential are key points for achieving learning goals. The learning process that takes place will be in accordance with what the students expect and expect from the teacher, and of course this does not conflict with the teacher. The teacher is the component that most impacts the creation of quality educational processes and results (Mulyasa, 2009). Related to the teacher's strategy in increasing learning, motivation, strategy is a plan, steps and a series to achieve a goal, so in learning, the teacher is thirsty to make a plan, steps in achieving a goal (Yamin, 2013). The findings of the study from (Hermansyah, 2021) showed that the students' problems in speaking English not only beacause of the components of speaking such as; pronunciation, expression, vocabulary, and fluency but it could be comes from themselves those are encouragement, confidence and bravery. In an effective learning process, teachers have very important strategies during the teaching and learning process.

The teacher is the main learning component because the success of the teaching and learning process is determined by the teacher. The learning process is taken at Muhammadiyah Junior High School during the Covid-19 pandemic is done based on teaching learning process between teachers and students. This research focuses on teacher strategies in teaching speaking on the material (introduction) including the aspect of speaking skill, Which is taught in seventh grade with competency standards as stated in the Curriculum 2013 is to compile simple oral and written texts express and respond to selfintroductions, in a very short and simple manner, by paying attention to social functions, text structure, and correct language elements and appropriate context. Even though, the function of the question sentence is very dominant for the effectiveness of the implementation of interviews and interview results, so in the teaching and learning process the teacher must be able to design interesting and fun learning, by choosing relevant methods so as to increase 
students learning motivation, especially the motivation of students learning online. considering that currently it is still in the covid-19 pandemic.

Nowadays foreign language acquisition research has recently suggested that some conscious attention to grammatical forms is necessary to develop high levels of accuracy in the target language (Hermansyah H. , 2018). "Brown (1992) states one of the major obstacles learners has to overcome in learning to speak is the anxiety generated over the risks of blurting things out that are wrong, stupid, or incomprehensible. Because of the language ego that informs people that "you are what you speak," learners are reluctant to be judged by hearers. Our job as the teachers is to provide the kind of warm, embracing climate that encourages students to speak however halting or broken those attempts may be. One of the more complicated problems of second language learning and teaching has been defining and applying the construct of motivation in the classroom (Hermansyah, 2021)." Similar obstacles faced by student at Muhammadiyah Junior High School Prabumulih, Namely in learning to speak, the problem is anxiety caused by a lack of self-confidence and student still feel ashamed to speak English in front of the more obstacles that students must face in learning to speak is anxiety that is caused by a lack of of selfconfidence and student still feel embarassed to speak English in front of the class.

The various efforts made by Muhammadiyah Junior High School Prabumulih teachers, namely Mrs. Fitria, M.Pd, to carry out the learning process during the pandemic are inseparable from virtual media as a facilities of supporting the fluency learning process. Of course, virtual teaching online is a new experience for Mrs. Fitria, M.Pd, so that some obstacles are often encountered during the teaching and learning process. For teachers, the obstacles faced are planning learning activities that are in accordance with the situation and conditions of students. For students, "In the classroom, when students have opportunities to make their own choices about what to pursue 
and what not to pursue, as in a cooperative learning context, they are fulfilling this need for autonomy (Hermansyah, 2021)."

Sari (2018) stated that "She had some worries about how to implement the strategies in the classroom. The number of the strategies was another obstacle as the students might have found them confusing. Another question in mind was about the success of the students' using the comprehension strategies independently as many of these reading comprehension strategies were new to the students." It was inconceivable that there would be events like this before the exam. It's not easy to change a mature plan in learning into something new, especially without meeting face to face. According to Susanti (2020), stated that she was accustomed to preparing lessons using internet facilities, her difficulty was planning media that based on her abilities and the circumstances of her students. In addition, there is no face to face so there is no direct communication. Based on the background above, the writer was interested in conducting research on the title "Teacher's Strategies in Teaching Speaking During Covid-19 Pandemic".

\section{Research Methodology}

In this research, the writer used descriptive qualitative research that focused on the teacher's strategies. Research with a qualitative approach emphasizes the analysis of the process of thinking inductively related to the dynamics of the relationship between observed phenomena, and always uses scientific logic. Qualitative research methods are often called naturalistic research methods because the research is carried out in natural conditions (natural setting) (Sugiyono, 2010). The qualitative approach is indeed social reality as a holistic/whole, complex, dynamic, full of meaning, and the symptom relationship is reciprocal. Qualitative research is a research procedure that produces descriptive data in the form of writing about people or people's words and their visible or visible behavior. Based on the problems posed in this research 
emphasizing process problems, the best type of research and strategy is descriptive qualitative research. This type of research could be to capture a variety of qualitative information with thorough and nuanced descriptions that are more valuable than simply number or frequency statements in the form of numbers. The strategy used is a case study, because the problems and research focus have been determined in the proposal before the the writer jumps in and delves into problems in the field, then the research can also be categorized as an Embedded Case Study Research (Sutopo, 2002).

\section{Findings and Discussion}

\section{Findings}

\section{Teacher's Strategy in the Speaking Learning Process}

The used of strategies in the online learning process was indeed very necessary, where during the pandemic, the face-to-face learning process was blocked so that students were forced to learn remotely. In choosing a strategy to be applied in learning, the teacher couldn't just choose randomly. The choice of strategy must be adapted to the circumstances of the school environment, classroom conditions, student circumstances and the objectives of the learning. Mrs. Fitria, M.Pd as an English teacher for grade VII Junior High School Muhammadiyah Prabumulih. explained that the method commonly used when teaching speaking online was as follows.

"I used the Distance Learning (PJJ) method, as stipulated by our Minister of Education and Culture, Nadiem Makarim. This method was the most appropriate solution to use during the Covid-19 Pandemic situation."

During the current pandemic, this was a challenge for Mrs. Fitria, especially in teaching speaking material, even though studying online, learning English, especially speaking material, must still be done even though you can use applications such as: Zoom Meeting. Goegle meeting, 
WhatsApp, and YouTube. So that the teaching and learning process continues with the help of applications available in today's modern era, there was teacher and students interaction in mastering online learning. Indeed, the phenomenon in the field shows that online learning requires a fairly large internet quota, the stability of the internet network. If there are problems regarding the signal and the limited internet quota that students have, then Mrs. Fitria, M.Pd provides a solution to utilize WhatsApp Group as an application or study space by using the voicenote application on WhatsApp and utilizing Goegle Classroom. This effort was made as an alternative to the online learning system to keep it running.

At Junior High School Muhammadiyah Prabumulih. the teacher teaches at school as usual by applying health protocols and students learn at home. It can be seen from the picture above that it facilitates teachers to teach with the availability of computers, so that all teachers can use them as a teaching tool, not focusing on using cellphones as an alternative to online teaching tools. Researcher also found data that Mrs. Fitria, M.Pd used the Personalized Method in the discussion system, this was used to be able to provoke discussion and test students' understanding through calling their names one by one through the zoom application, but this depends on the situation and condition of the students. as well as the learning objectives.

\section{Types of Strategies for Teachers Teaching English Online}

Online learning regarding speaking material taught to grade VII students of Junior High School Muhammadiyah Prabumulih. as an effort to suppress the spread of Covid-19 was carried out using learning applications and virtual classroom services that could be accessed via the web using the internet network. In general, some students were satisfied about the flexibility of the implementation of learning. Because students were not pressured by time 
because they could determine for themselves the place where they want to take part in the learning. Various online learning applications can be used such as Zoom Meetings, Goegle Classroom, YouTube media and even WhatsApp communication media are also used as a learning space.

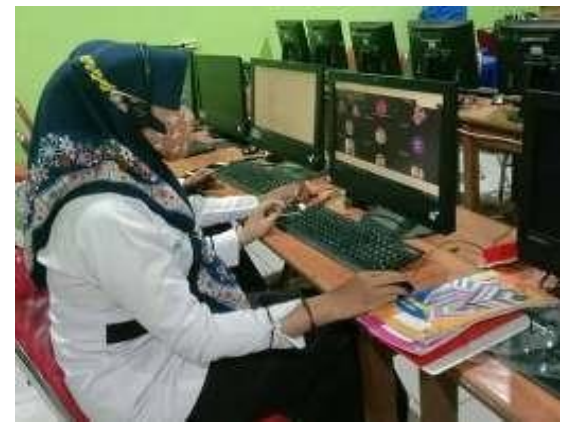

Picture 1. Mrs. Fitria, M.Pd was carried out online learning used the Zoom Meeting application.

(Photo: Arya, April 2021).

In the teaching and learning process, it couldn't be separated from the role of a teacher. The teacher has a very important role in the online learning process because it was the teacher who will guide students, understand students and rectify if there are errors in students' thinking. In this situation the teacher has a very important role in motivating students to learn. However, the teaching and learning process will not be successful if the teacher was not professional and competent in their field. In addition, to be good educators, teachers must also understand and understand the character of each student. Because it is well known that every student must have a different character. To unite these characters, the teacher must have the right strategy in teaching speaking. Especially during a pandemic.

In general, students often think that learning to speak during a pandemic was difficult, making them unable to understand it. Mrs. Fitria, M.Pd also expressed the same opinion about the response of most students to speaking lessons, as told in the interview with the researcher below: 
"Yes, that is true, in fact the students are less enthusiastic, and less enthusiastic about learning. They cannot understand the lessons well, especially speaking lessons because they should practice directly in class, therefore I really try to be able to develop appropriate learning strategies so that the online learning process becomes interactive."

Every student must have different characters and opinions about what theysee and what they feel while studying online. there are even students who say thatonline English lessons make them confused, This opinion was expressed by Farhan Mataram, a class VII B student at Junior High School Muhammadiyah Prabumulih. who shared his opinion through interviews with researcher below:

"Actually learning English online is difficult, but the way Mrs. Fitria teaching always provides us with interesting material from the learning videos from YouTube so that it helps us to understand the speaking material."

Then in addition to Farhan Mataram, there was another student named Widya Ningrum who also agrees with Farhan Mutaram, Widya Ningrum shared his impression on the subject of English to researcher through joint interviews with researcher as below:

"We really like it when learning to speak with the help of the media, especially with animated YouTube videos so that we don't got troubled and confused about practicing it because we already had been examples from YouTube."

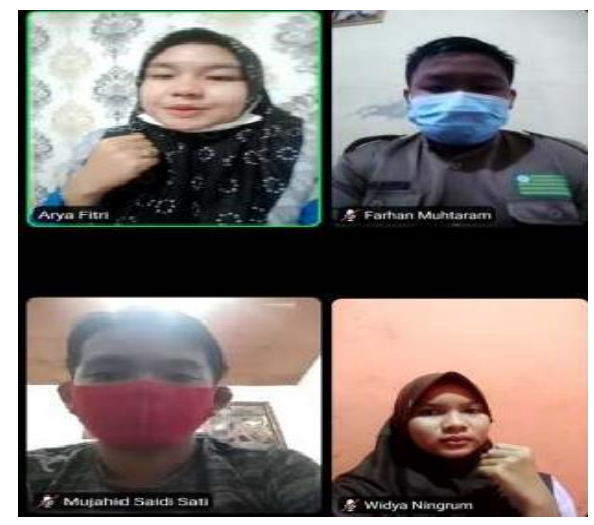

Picture 2. Farhan Mataram and Widya Ningrum shared 
the experience of learning speaking in English. (Photo:

\section{Arya, April 2021)}

In speaking learning, students were required to actively interact and communicated, So strategy was very important to be applied in the learning process. Based on the analysis of interview data with Mrs. Fitria, MPd regarding the types of strategies used in online learning was the expository strategy. Mrs. Fitria said that "The type of expository learning strategy I use in online learning, with the expository strategy in speaking learning emphasizes the process of delivering material verbally from a teacher to students with the intention that students can master the subject matter optimally." Based on direct observation by the researcher, Mrs. Fitria, M.Pd could optimize the expository learning strategy for class VII.B students in speaking material, because if it is not the teacher who optimizes, students did not receive learning well. Mrs. Fitria usually gave her lessons in classes starting in classes and schools. Mrs. Fitria, M.Pd applies an exposure strategy with the principles of an Expository Learning Strategy, namely goal-oriented, communication principles and sustainable principles. With Mrs. Fitria's exspository strategy, she aims to overcome student learning difficulties individually and be able to solve problems that arise during the Covid 19 pandemic.

As has been stated by several seventh grade students at Junior High School Muhammadiyah Prabumulih. that the subject of English with online speaking material was indeed difficult but with the help of video it reduces their difficulties. then the teacher must control the conditions as much as possible, namely by using various appropriate strategies. The purpose of using the right strategy is so that students can follow online lessons well, were not bored and do not feel bored and can capture the material taught by the teacher properly. 


\section{Discussion}

Strategy was an outline of direction to act in an effort to achieve predetermined goals. Associated with teaching and learning strategies can be interpreted as general patterns of teacher and student activities in the embodiment of teaching and learning activities to achieve the goals outlined. Thus, the strategy was basically planned steps that have a broad and deep meaning resulting from a process of deep thought and reflection based on certain theories and experiences. Language learning strategies can be divided into two main categories. They are a direct strategy and an indirect strategy (Hermansyah, 2016).

Based on the analysis of research data, the learning strategies used by Mrs. Fitria, M.Pd in teaching speaking material to class VII.B students fell into the direct category. Direct learning strategy is learning that is directly directed by the teacher through specific tasks that must be completed by students under the direct supervision of the teacher. The online teaching method that Mrs. Fitria, M.Pd used the assignment method. Assignments were given through the Goegle Classroom learning application and the results of student worksheets are collected directly to the school so that Mrs. Fitria, M.Pd can direct and supervise the task completion process and be able to solve problems faced by class VII.B students in completing assignments. The direct strategy category was analyzed according to the data the researcher obtained in the field, Mrs. Fitria, M.Pd used Zoom Meetings as an application for face to face with students in an effort to deliver material directly, an effort to provide direct examples to students regarding speaking fluency, speaking accuracy, intonation and the accuracy of the meaning of speaking learning. The direct learning strategy is teacher-centered learning, therefore this learning implies direct interaction between teachers and students. Zoom Meeting assisted learning process was very effective to use because there was direct interaction between teachers and students. When Mrs. Fitria, M.Pd gave an 
example of speaking dialogue, the students then explored to recite. The process of imitating students takes turns. In speaking learning, the learning material being studied was divided into smaller sections and introduced directly to the students. Based on the type of strategy, Mrs. Fitria, M.Pd used an exspository strategy. The expository learning strategy is a learning strategy emphasizing the process of delivering material verbally from a teacher to a group of students with the intention that students can master the subject matter optimally.

From the way she conveyed the material, the first stage of Mrs. Fitria, M.Pd was preparing lessons that have been arranged based on basic competencies: "Being grateful for the opportunity to learn English as the language of instruction for international communication", core competence: Appreciating and living the teachings of her religion ", and indicators: "Composing simple spoken and written texts to state, ask, and respond to selfintroductions, in a very short and simple manner, by paying attention to social functions, text structure, and linguistic elements that are correct and in context" through learning spaces such as Zoom Meetings, WhatsApp and Goegle Classroom is delivered directly and compiled in PPT form, then Mrs. Fitria, M.Pd describes the material directly using a Zoom Meeting and in the form of a PDF chatt to Goegle Classroom and WhatsApp if students have problems joining the zoom class.

Then Mrs. Fitria, M.Pd took attendance to ensure the readiness and attendance of all students to receive the material, after the attendance was completed then presented and explained the learning material through the Zoom Meeting application, as well as WhatsApp voice notes and Goegle Classroom, at this stage Mrs. Fitria, M .Pd send teaching material directly to students accompanied by giving daily assignments to find out students' understanding of the speaking material.

Furthermore, the discussion of learning procedures on the used of English 
teaching methods. Mrs. Fitria used the assignment method and the question and answer method as an effort to achieve the learning objectives, namely: 1) Students can compile self-introduction texts orally, 2) Students can use appropriate and related vocabulary in compiling self-introduction oral texts, 3) Students can use correct and correct pronunciation in composing a selfintroduction oral text.

The assignment method is a way of presenting lesson material. In this method, Mrs. Fitria, M.Pd gave a set of tasks that must be done by grade VII.B students, either individually or in groups. Tasks in the speaking material include the task of mimicking greeting the unknown or already known in turn in a Zoom Meeting forum, the task of introducing yourself and others assisted with voice notes as a voice recording tool when collecting speaking assignments in the form of: compiling oral self-introduction text, using Appropriate vocabulary is related to compiling self-introduction oral texts, correct and proper pronunciation practices in compiling self-introduction oral texts compiled by students independently. In order for the assignment method to be carried out effectively, the teacher paid attention to the steps to apply the speaking material teaching method as follows:

a. The assignment on the topic of Introducing My Self was planned clearly and systematically, especially the purpose of the assignment and how to do it, the purpose of the assignment was communicated by the teacher to grade VII.B students so that they knew the direction of the task being carried out.

b. The task of introducing my self topic must be understood by class VII.B students, when to do it, how to do it, how long the assignment must be done, individually do the introductions. These efforts in giving assignments greatly determine the effectiveness of using the assignment method in learning. 
c. If the task is in the form of a group assignment, efforts need to be made so that all group members can be actively involved in the process of completing the task, especially if the assignment is completed outside the classroom. The data that the researcher obtained in the field Mrs. Fitria had not given group assignments because she remembered the learning system in their respective homes.

d. The teacher controls the process of completing assignments carried out by grade VII.B students. If the assignment was completed in class, The teacher could asked students to submit assignments directly to the school, this was regulated by the school as a policy and an alternative to ensure students are directly involved in the work of assignments, the collection of assignments was directly delivered to the school, while providing motivation and guidance, especially for class VII.B students who have difficulty completing assignments. If the assignment was completed in class, Mrs. Fitria, M.Pd could control theprocess of completing the assignment through consultation from class VII.B students. Therefore, in assignments that must be completed outside of the completion of class VII.B students are asked to provide a report on the progress of the task being done.

e. For the assessment, it seems that she gave a proportional assessment of the assignments performed by class VII.B students with excellent success standards (100), very good (90), good (80), average (70), poor $(\leq 60)$. The assessment given should not only focus on the results of the assignment, but also need to consider how the process of completing the task was necessary. Assessment should be given directly after the assignment was completed, in addition to generating interest and enthusiasm for class VII.B students' learning, it also avoided the accumulation of work of class VII.B students who have to be examined, said the teacher.

Furthermore, the discussion of the question and answer method was a 
way of presenting teaching materials in the form of questions that require answers to achieve goals. Questions can arise from Mrs. Fitria, M.Pd as a teacher who provided the opportunity to ask questions, it could also be from grade VII.B studentswho had difficulties in understanding the speaking material, as well as answers that can come from Mrs. Fitria, M.Pd and from class VII.B. Questions could be used to stimulate the thinking activities and creativity of class VII.B students. Therefore, they should be encouraged to seek and find appropriate and satisfying answers. In searching for and finding answers to these questions, grade VII.B students try to connect the knowledge and experiences they have with thequestions they will answer.

The things that Mrs. Fitria, M.Pd paid attention to in the use of the question and answer method were as follows:

a. Mrs. Fitria, M.Pd has fully mastered the speaking material

b. Mrs. Fitria, M.Pd prepared the questions that were asked to students of class VII.B in such a way, so that learning did not deviate from the material being discussed, leading to the achievement of learning objectives and in accordance with the thinking abilities of class VII.B students. A good question had the following criteria:

1) Giving a reference, a question that provided a reference was a form of question that was previously given a brief description of what will be asked, so the question was a continuation of the lecture or story of Mrs. Fitria, M.Pd.

2) Focusing the answer, the questions asked need to be focused on what was the goal of the learning activity.

3) Providing guidance, Mrs. Fitria, M.Pd could be guide grade VII.B students with questions that lead them to the correct answer.

4) Tracking the answers of class VII.B students, Mrs. Fitria, M.Pd asked several questions again even though the answers to the first questions 
were correct.

When viewed from the objectives of learning and evaluation it could be discussed that the learning objectives were achieved by measuring the ability of students in composing oral self-introduction texts, using appropriate vocabulary related to compiling self-introduction oral texts, correct and appropriate pronunciation practices in compiling self-introduction oral texts .

From the research documentation data on the value of the assignment obtained from Mrs. Fitria, M.Pd, the researcher could discuss that the data in the field was found to be in line with Djamarah's theory "Associated with teaching and learning, strategy can be interpreted as general patterns of student teacher activities in the realization of teaching and learning activities to achieve the goals outlined (Djamarah, 2013) ". Judging from the evaluation of the aspects of the assessment of pronunciation and intonation, the average student had errors but did not interfere with meaning. In the aspect of fluency, students are in the very fluent category and the accuracy of the meaning was on average right.

Based on the achievement of learning outcomes with an average score above 80 , with a standard of success of good (score 85) totaling 6 students, very good (score 90) totaling 9 students, it can be concluded that learning English with online speaking material was carried out by Mrs. Fitria, M.Pd was achieved in accordance with the learning objectives and went well in accordance with the learning strategies chosen as the right strategy during the Covid 19 pandemic.

Furthermore, The finding of this research also had been similarities with journal Sutarto "Teacher Strategies in Online Learning to Increase Student Learning Interest During the Covid-19 Pandemic". That focused on the problem of Teacher Strategies in increasing student interest in learning during the Covid19 pandemic. This was a focused on teacher strategies in teaching online 
during the Covid-19 pandemic which was of course very different from learning strategies that were not during the Covid-19 Pandemic. Before the pandemic at Junior High School Muhammadiyah Prabumulih used an Enquiry-Based Learning, meanwhile at the time of the Covid-19 pandemic there were variations in the strategies used by the teacher, namely the expository strategy after research on expository strategies could be followed by students when learning online. Online learning difficulties could be overcome with expository strategies because there was an assignment method that could be train students to understand learning material independently so that learning objectives could be achieved even when studying at home.

\section{Conclusion and Suggestion}

Based on the results of data analysis conducted by research, it can be conclude that teaching objectived were formulated according to the online learning system, namely students were able to introduce themselves smoothly, seen from observations during the learning process at the learning exploration stage. Meanwhile the speaking approach to understanding learning was followed by skills in learning English, from the research it could be concluded that students are able to interact with their peers in a zoom forum, (Example Student A: Hi, I'm Arya, Student B: Hello, I'm Fitri) The understanding approach that was considered the most appropriate with an online learning system. And then the online teacher learning method with virtual media as a supporting means used two learning methods, first, the assignment method through the Goegle Classroom application, the results of the answer sheets were collected directly to the school, then the second learning method was question and answer through zoom media and WhatsApp Group. Meanwhile the criteria for the success of learning speaking with a rubric for assessing aspects of pronunciation, intonation, fluency and accuracy of meaning. With the standard of success of excellent (100), very good (90), good (80), average (70), poor ( $\leq 60)$. From the results of the research, the researcher hoped that teacher 
created creative and fun learning through appropriate teaching strategies during the Covid 19 pandemic.

\section{Reference}

Anjayani, Y.D. (2016). Ekserimentasi Model Pembelajaran Two Stay Two Stray (TSTS) Pada Materi Garis Singgung Lingkaran Ditinjau Dari Sikap Sosial Kelas VIII Semester Genap SMP Negeri 16 Suarakarta. Tesis. Surakarta: FKIP Universitas Sebelas Maret.

Daryanto. (2010). Media Pembelajaran. Yogyakarta : Gava Media.

Djamarah, S. B. (2013). Strategi Belajar Mengajar. Jakarta: PT Rineka Cipta.

Hermansyah. (2016). Language Learning Strategies Used by The Sixth Semester Students of English Education Study Program. English Empower, 36.

Hermansyah, H., \& Santoso, H. (2018). Teaching English Grammar with Doctogloss. Holistics, $10(20,23)$.

Hermansyah. (2021). Self Talk Strategy in Improving The Eleventh Grade Students' Speaking Ability. SMART. Journal of English Teaching and Applied Linguistic, 6(1), 1-6.

Jaya, A., Hermansyah, H., \& Rosmiyati, E. (2019). The Implemetation of projectbased learning in increasing speaking achievement and Self-confidence. Indonesian Educational Administration and Leadership Journal, 1(1), 4-14.

Mulyasa, E. (2009). Menjadi Guru Profesional. Bandung: PT. Remaja Rosdakarya.

Sari, Dewi K., Pratiwi, E., and Ana. (2018) Effective Reading Strategies for Reading Skills. Esteem 2429, Ji2, 6.

Sugiyono. (2010). Metode Penelitian Pendidikan Pendekatan Kuantitatif, kualitatif, dan R\&D. Bandung: Alfabeta.

Sulo, U. d. (2005). Pengantar Pendidikan. Jakarta : PT. Rineka Cipta.

Susanti, A. (2020). Layanan Pembelajaran di Rumah Saat Pandemi Covid-19. In T. G. Inggris, Pengalaman Baik Mengajar Dari Rumah di Masa Pandemi Covid-19 (p. 5). Jakarta: Kementerian Pendidikan dan Kebudayaan. 
Fitri, Hermansyah, Pratiwi, Aswadjaya

Teacher's Strategies In Teaching Speaking During Covid-19 Pandemic

Yamin, M. (2013). Strategi dan Metode dalam Model Pembeljaran. Jakarta: GP Press Group. 